\title{
海岸砂丘・盛土による津波減災効果の検討 STUDY ON TSUNAMI MITIGATION EFFECT OF COASTAL DUNE AND FILL
}

\author{
前川俊明 ${ }^{1} \cdot$ 二瓶泰雄 ${ }^{2} \cdot$ 中田遥香 ${ }^{1}$ \\ Toshiaki MAEKAWA, Yasuo NIHEI and Haruka NAKADA \\ 1 学生員 学 (工) 東京理科大学大学院 理工学研究科土木工学専攻修士課程 \\ （干278-8510 千葉県野田市山崎2641） \\ 2正会員 博 (工) 東京理科大学准教授 理工学部土木工学科（同上）
}

\begin{abstract}
Tsunami caused by 2011 Great East Japan Earthquake gave enormous damage to the plains where countermeasures against huge tsunami disaster was not done. In order to clarify the tsunami mitigation effect of coastal dune and fill, in this study, we surveyed inundation depth and structural damage in Asahi City, Chiba Prefecture and Natori City, Miyagi Prefecture. The results showed that coastal dune in which the height were comparable to tsunami height, decreased the inundation depth and structural damage in the hinterland of the dune. It means that the coastal dune and fill can be an effective countermeasure for tsunami disaster in the plains with sandy beach. These results were dominant in Asahi City with the coastal dune with the length more than $3 \mathrm{~km}$ along the coastline.
\end{abstract}

Key Words : tsunami, coastal dune, fill, mitigation effect, 2011 Great East Japan Earthquake

\section{1. 序論}

2011 年東日本代震災では，太平洋沿岸部の広範囲にわ たり巨大津波による被害を受けた ${ }^{1)}$ 。この巨大津波災害 の大きなの特徽の一つとして, 明治・昭和三陸津波で被 害が集中したリアス式海岸だけでなく，宮城県から千葉 県にわたる平野部にまで大きな被害が見られたことであ る $\left.{ }^{2}, 3\right)$. 特に, 宮城県仙南平野では, 内陸 $5 \mathrm{~km}$ まで浸 水したことが報告されている ${ }^{3)}$. 現在, 被災地において, 津波に対して粘り強い海岸堤防の計画や南海トラフ巨大 地震津波への防災対策を視野に入れた平野部における沿 岸整備について活発な議論がなされつつある $\left.{ }^{40}, 5\right)$.

古くから津波防災対策に努めてきたリアス式海岸の沿 岸部では, 岩手県普代村における普代水門のように津波 に対して背後の住宅地への浸水被害を大幅に軽減させた 例もあれば，同県宮古市田老地区の防潮堤のように巨大 津波が越流し，背後地の甚大な被害を出した例もあるの。 本震災で大きな被害を受けた平野部で一般に見られる砂 浜海岸において, 普代水門や田老海岸のような高さ $10 \mathrm{~m}$ を越す巨大防潮堤を連続的に建設することは困難である. 砂浜海岸における他の津波対策として, 海岸林 (防潮林) を利用した津波減衰効果の研究が数多くなさている ${ }^{\text {わ) }}$. これにより，防潮林は津波到達時間遅延や漂流物補足効 果などを有することが指摘されているが，津波の波高減
衰効果が十分でないことや塩害などによる維持管理上の 問題点も指摘されている.

一般に, 平野部における砂浜海岸では, 背後の防潮林 前には砂丘が存在寸るが, この海岸砂丘がもつ津波防災・ 減災効果については, Tanaka et al. ${ }^{10)}$ や下園ら ${ }^{11)}$ で指摘さ れている程度であり，未解明な部分が多い，海岸砂丘や それと類似した盛土が一定の津波防災・減災効果を有し ていれば，既存の海岸砂丘を生かした津波対策が可能と なり, コンクリート製防潮堤の場合と比べて, コスト面・ 環境保全面で極めて優位になるものと考えられる.

それに対して, 著者らは, 市全体の約 $1 / 3$ が浸水した 宮城県名取市において津波被害調査を実施し，平野部に おける家屋被害の特徴や海岸付近に位置する人工砂丘の 津波減災効果の一端を明らかにした (二瓶ら ${ }^{12)}$, 以下, 前報と呼ぶ) 。本研究では, 前報に引き続き, 上記の宮 城県名取市に加えて, 千葉県旭市における津波被害調查 を行った結果を用いて，海岸砂丘・盛土の津波減災効果 を検証することを試みる。ここでは，家屋被害調査と浸 水深調査の二つの現地調査を実施した. 両調査サイトで は，後述するように津波浸水高が全く異なるが，津波浸 水高とほぼ同程度の高さで, 沿岸方向長さが全く異なる 人工砂丘（盛士）が存在している.また, 名取市には, 大小の人工砂丘が存在している，これより，両サイトに おける家屋被害状況やそれらに対する砂丘効果を抽出寸 


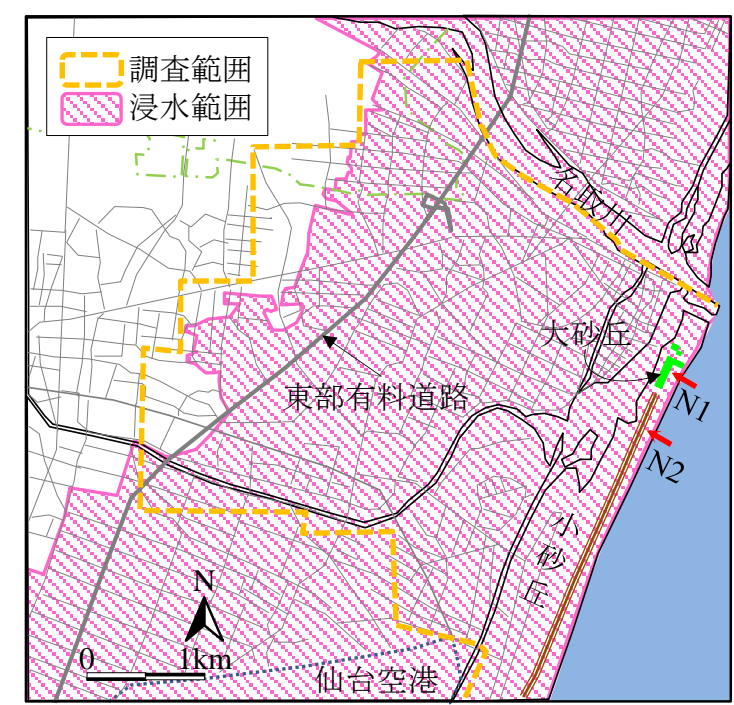

(a) 名取市

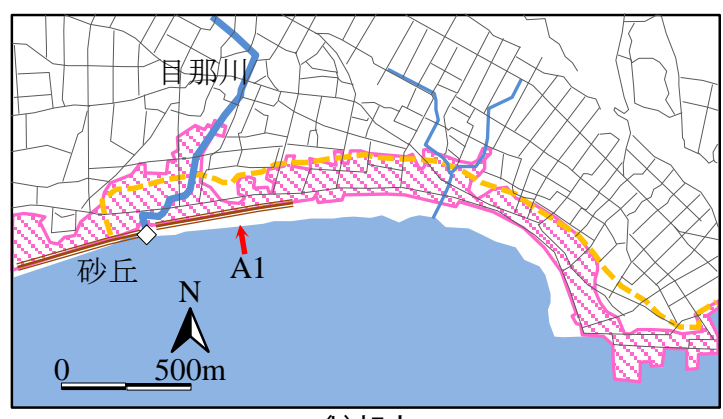

(b)旭市

図-1 調査範囲と浸水範囲 ${ }^{13}$

ることにより，津波減災効果に対する砂丘の高さや沿岸 方向幅の影響を検討寸る.

\section{2. 研究方法}

\section{（1）調査サイト}

図-1 は，本研究で対象とする観測サイトにおける調査 範囲と浸水範囲を示す，この浸水範囲は，国土地理院の 公開データ $\left.{ }^{13}\right)$ である. 名取市は, 北側に名取川を有し, この名取川に津波が遡上するとともに, 海岸からも内陸 側に遡上し, 海岸から $3 \mathrm{~km}$ の東部有料道路をも越え, 死 者・行方不明者数は 986 名に上る. ただし, 盛土された 東部有料道路を挟んで海側と陸側とでは被害状況が大き く異なるため, 東部有料道路が “第二防潮堤” としての 機能を発揮したことが分かっている. 一方, 旭市は千葉 県北東部に位置し, 九十九里浜の最北端にある. 同市で は震源から遠方に位置しながら死者・行方不明者 15 人と 千葉県最大の津波被害を受けた。

調査範囲は，同図中の点線で囲まれた範囲であり，両 サイト共に基本的に浸水範囲をカバーし, 家屋被害が確 認されないところまでを対象とした. 名取市では, 概ね, 沿岸方向に $3.5 \mathrm{~km}$, 海岸から陸側へ $4 \mathrm{~km}$ までを対象とし, 合計 5253 棟の建物被害状況を調べた. 旭市では, 沿岸方

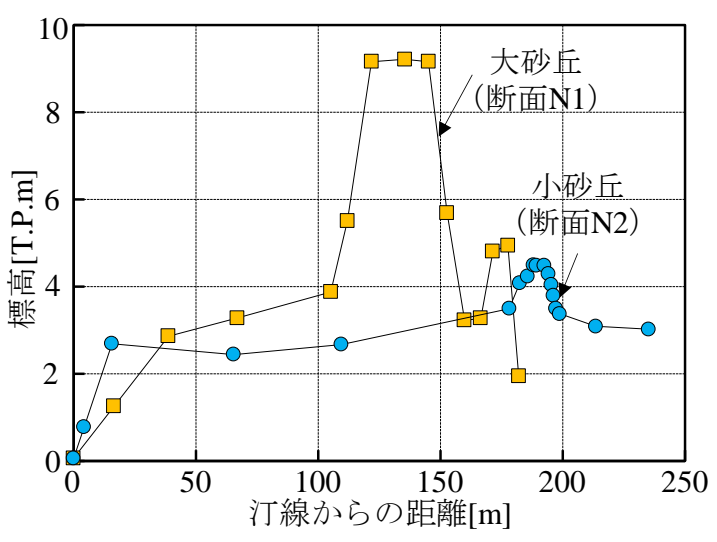

(a) 名取市

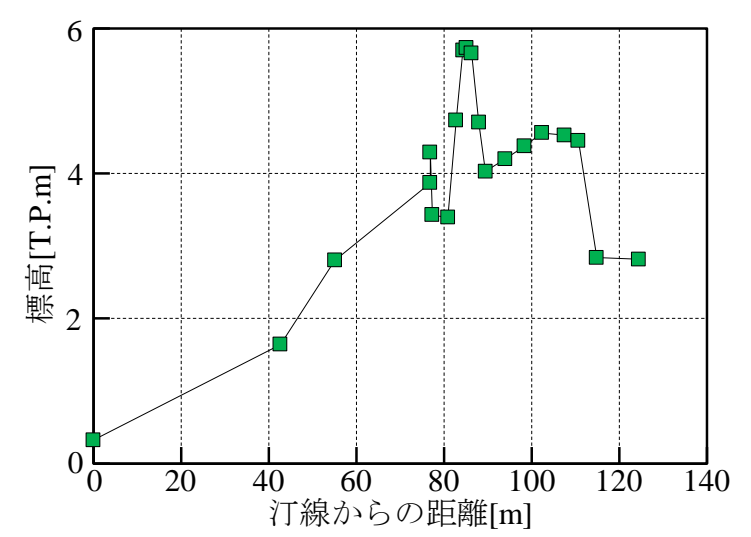

(b) 旭市 (断面 A1)

図-2 観測サイトに存在する砂丘の断面形状

向に被害状況の明確な差異があり，それを含める形で沿 岸方向に $4 \mathrm{~km}$ ，海岸から陸側へ $0.5 \mathrm{~km}$ の距離の範囲に存 在した計 3478 棟について，建物被害状況を調査した。

これらの調査サイトには，それぞれ海岸砂丘（盛土） が存在する. 名取市では, 図-1 に示寸ように, 閶上漁港 の南側に高さ9.1[T.P.m]の大人工砂丘が存在し, それは沿 岸方向に約 $200 \mathrm{~m}$ 存在する. また, その南側には, 高さ 約 4[T.P.m]の小砂丘があり, 沿岸方向に $3 \mathrm{~km}$ 続く.この 砂丘の岸沖方向の断面形状は図-2（a)に示すとおりである. この大・小人工砂丘の背後には防潮林が存在しており, 津波来襲後には, 概初倒伏した. 一方, 旭市においても, 図-2(b)に示す高さ 5.8〜 6.5[T.P.m]の砂丘が存在し, 対象开 イトの中央部から西側に $3 \mathrm{~km}$ 続く. 途中, 目那川 (図-1(b)) の河口部等では, 砂丘の切れ間が存在する.

\section{（2）調査方法}

本論文では，前報と同じく，家屋被害調査と津波浸水 深調査を行った．まず，家屋被害調査では，ゼンリンの 住宅地図を持参して，地図上に記された建物の被害状況 を確認し，家屋情報を収集した。この家屋被害状況とし ては，前報と同じく，庄司ら ${ }^{14)}$ に従い「全壊または基礎 のみを残した流出（以下，単に流出）」, 「二階損壊」, 


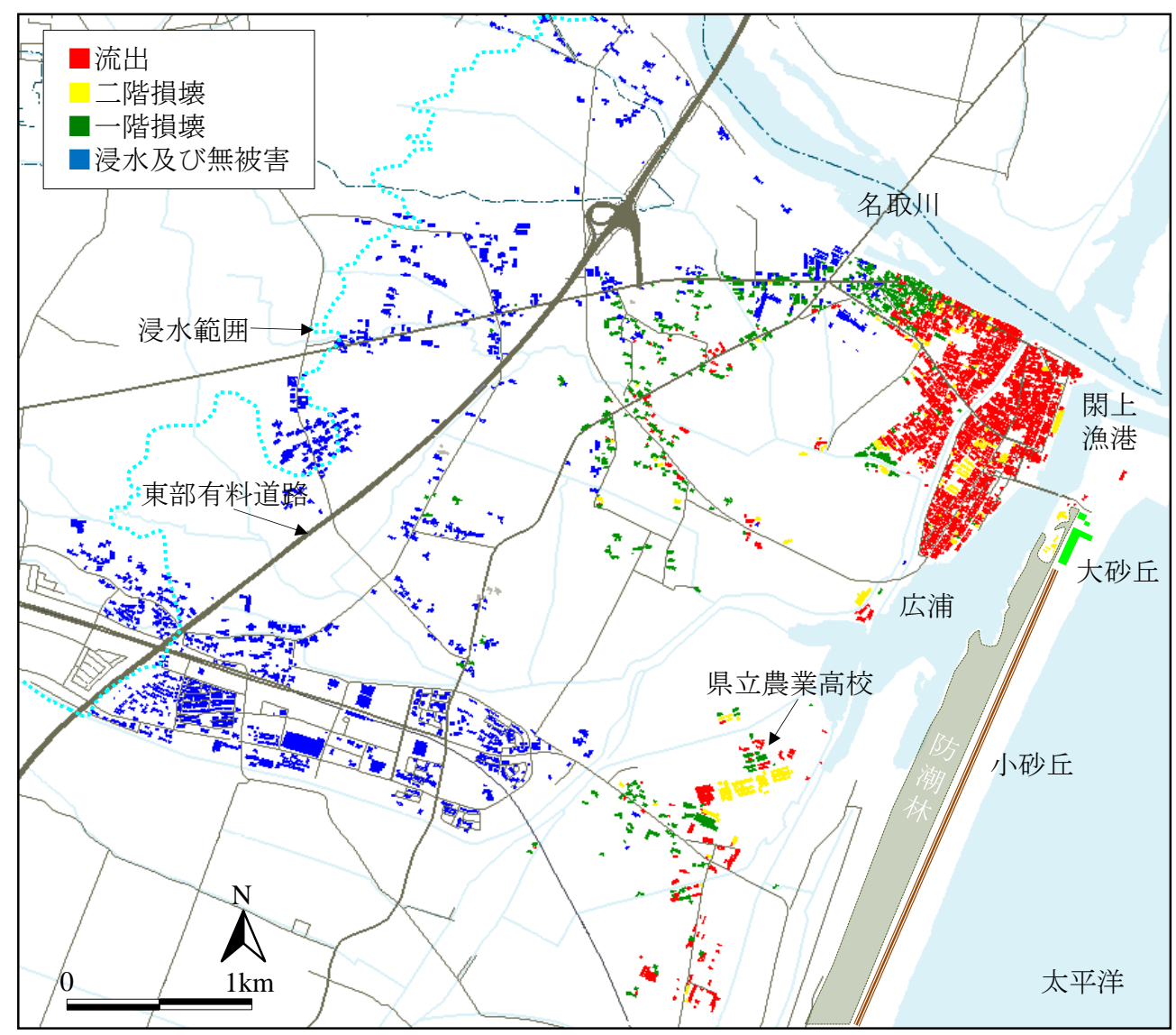

図-3 宮城県名取市における家屋被害状況マップ（前報 ${ }^{12)}$ の結果を一部修正）

「一階損壊」,「浸水及び無被害」の4段階に分類する. また家屋構造に関しては，撮影写真から後日判定した.

一方，浸水深調査では，VRS 方式 RTK-GPS（R4,

Trimble製）もしくはStatic GPS（FlexPak，NovAtel製）を用 いて現場での標高を算出し，その值とスタッフで読み取 った痕跡水位から浸水高を求めた。また，同 GPSを用い て, 前述した砂丘断面形状や周辺域の標高も計測した.

調査日は，名取市では 2011/5/11-13，6/11-12の二回にわ たり，それぞれ調査範囲の北東側と南西側を調査した. また，旭市では，2011/4/6 に全般的な視察を行い，同年 7/13 と $8 / 2$ の二回調査を行った. これらの調査日は, 両サ イト共に, 震災発生から数か月が経過しており, 家屋の がれき撤去も一部で行われていた，そのため，地元での 聞き取りと震災前後の衛星画像を元にして，調査時に「流 出」と判定された家屋の一部が残存していたことが判明 し，それらはまとめて「二階損壊」として扱った。

\section{3. 結果と考察}

\section{（1）調査サイト全体の被害状況}

宮城県名取市と千葉県旭市における家屋被害状況調査 から得られた結果をゼンリンデジタウンにプロットして 作成された家屋被害状況マップをそれぞれ図-3，4 に示 す.ここでは, 前述したように, 家屋被害状況を「流出」,
「二階損壊」，「一階損壊」，「浸水もしくは無被害」 の 4 段階で分類している. また, 関係する砂丘と防潮林 の位置も明示している，これより，名取市では，海岸線 から $1.5 \mathrm{~km}$ の範囲に流出した家屋が集中し，そこから $3 \mathrm{~km}$ 程度まで一，二階損壊，それより陸側では浸水もしくは 無被害であった。また，これらの被害状況を沿岸方向に 比較すると，同エリア北側（閖上漁港）と比べて，南側 （県立農業高校）の方が相対的に家屋被害が少ないよう に見受けられる．同エリア南側の海岸部には，高さ $4 \mathrm{~m}$ の小砂丘や幅 $350 \mathrm{~m}$ の防潮林があり，これらの抵抗体が 津波遡上を抑制した可能性が高い．また，大砂丘背後で は， RC構造物も含まれているものの，ある程度被害が軽 微な構造物が散見される.このように, 家屋被害状況は, 基本的には海岸からの距離と大きく関係しているが，沿 岸方向にも変化しており, 後者は砂丘や防潮林の存在と 関連していることが示唆された.

一方，旭市では，家屋被害が生じたエリアは海岸付近 に集中しており，かつ，同一エリアで流出・二階損壊・ 一階損壊の被害が混在している。また，家屋被害状況は 漁港近くの飯岡地区では顕著であるが，同エリアの西側 の海岸ではほぼ無被害であり，家屋被害状況が沿岸方向 に大きく変化しており,名取市とは異なる結果となった. 具体的には，対象エリア西側では，高さ約 $6 \mathrm{~m}$ の砂丘や 防潮林が連なっており，それらの背後において，家屋被 


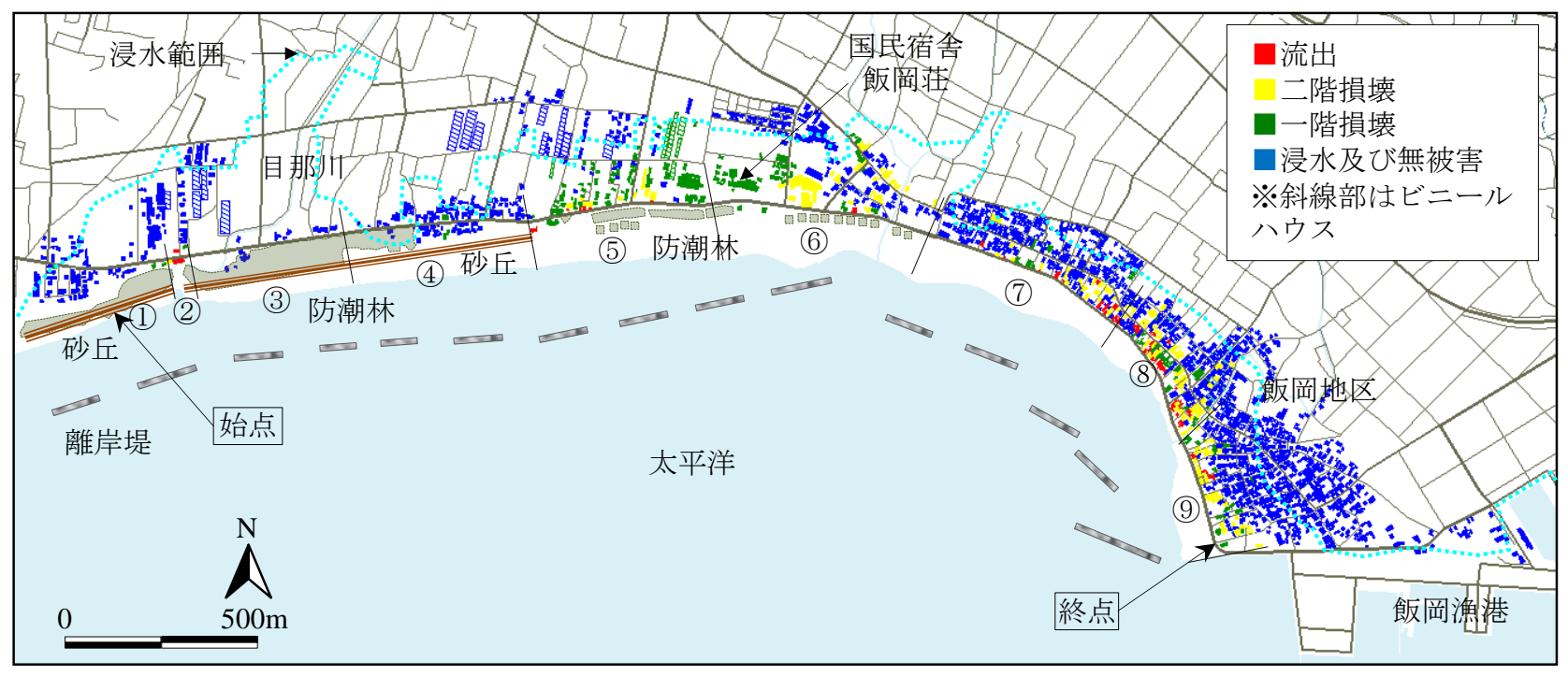

図-4 千葉県旭市における家屋被害状況マップ

害がほとんど見られない（図中(1)，(3)～(4)）。また，防 潮林のみが点在する(5)，(6) 間では，家屋被害は飯岡 地区よりは少ないものの，二階・一階損壊被害が見られ， 砂丘が存在した区間 (1), (3), (4)) よりも被害は大きい. (2)の目那川河口付近では砂丘の切れ間となるため, 流出 家屋が記録されている。このように，旭市では，相対的 に海岸付近に被害が集中寸ると共に，その被害状況が沿 岸方向に大きく変化し, それが海岸の津波抵抗体, 特に, 海岸砂丘と密接に関連寸ることが明らかとなった.

\section{（2）海岸砂丘条件が背後地の浸水深と家屋被害率に及ぼ す影響}

\section{a)浸水高と浸水深}

前述の被害マップから，海岸砂丘等により背後地の家 屋被害状況が異なることが示された。この海岸砂丘によ り得られる津波減災効果を定量的に検討寸るために，ま ず，名取市と旭市の観測結果に基づいて，汀線からの距 離に対する浸水高と浸水深, 標高の縦断変化を図-5に示 す. 名取市の結果については, 浸水深が浸水高と近いた め浸水深データを省略すると共に，観測エリアの北側と 南側に分けて表示寸る. このエリア南側は防潮林と小砂 丘の背後地である. 一方，エリア北側には大砂丘がある が，この効果は大砂丘背後 $800 \mathrm{~m}$ 程度に限定されている ので ${ }^{12)}$ ，ここでは，大砂丘背後 $250 \mathrm{~m}$ 以内に位置する 3 地点の観測データのみ「大砂丘背後」として表示し，そ の他のエリア北側は大砂丘の影響は少ないものと見なす。 また，旭市については，飯岡地区，砂丘背後（図-4中の (1)，(3)，(4)），目那川河口（同(2)）に分けて図示してい る.

これより，名取市の結果を見ると，海岸近くでは，浸 水高が 10[T.P.m]近くに達しており, 大砂丘の天端高さと 概ね一致している（図-2(a)）。また，汀線からの距離が

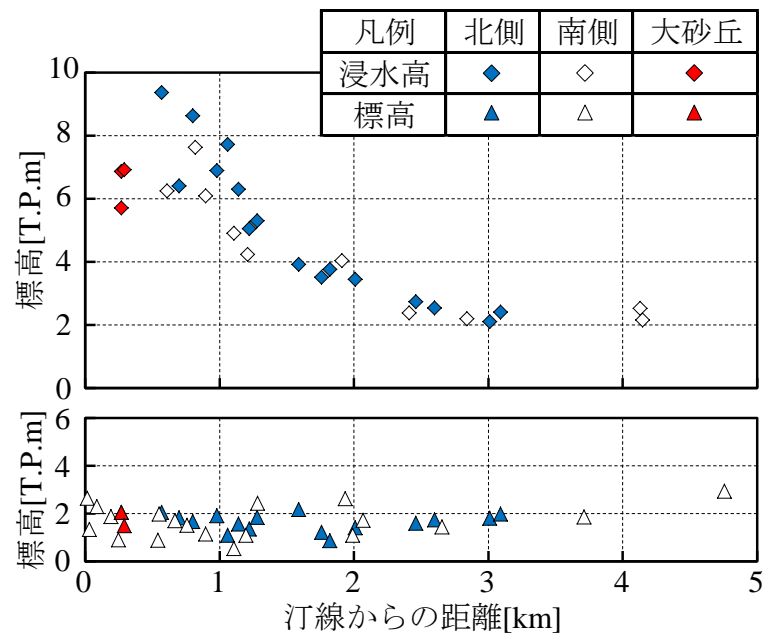

(a) 名取市

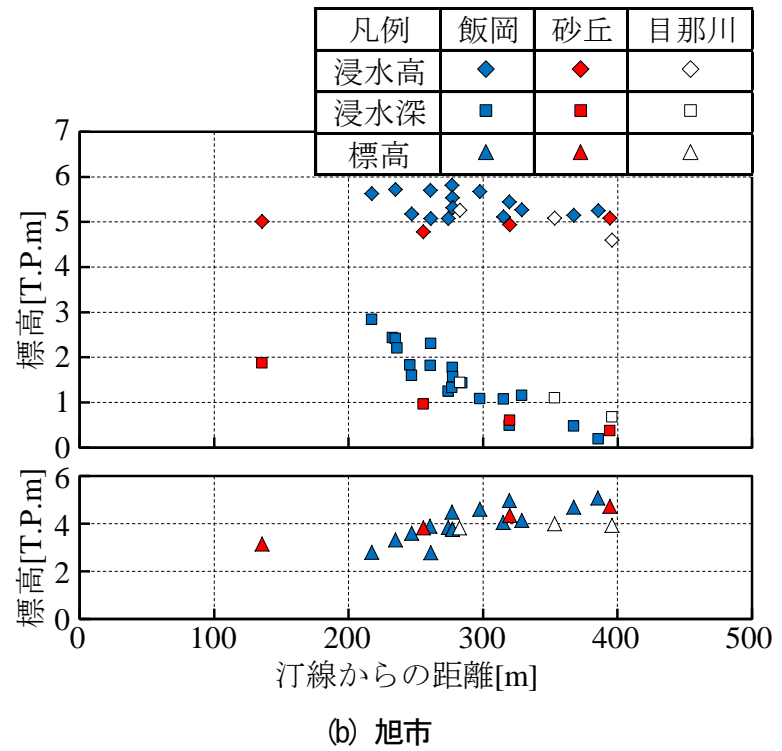

図-5＼cjkstart浸水深，浸水高と標高の変化

離れると，浸水高は指数関数的に減少している. この地 区全体で標高が概ね $2 \mathrm{~m}$ であり，南側と北側の差は顕著 


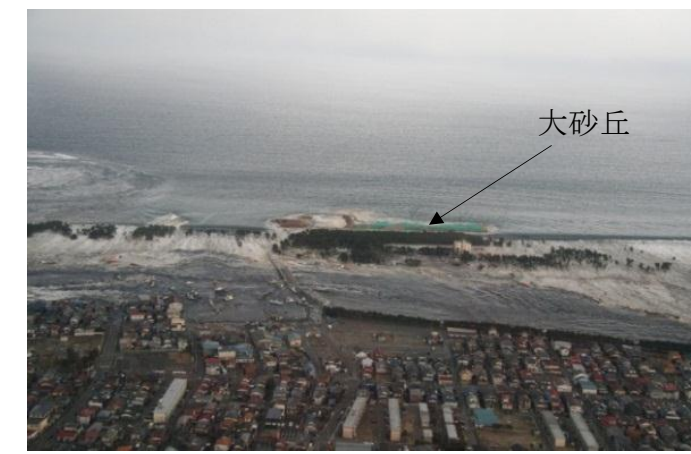

図-6 巨大津波襲来時における大砂丘周辺の状況（2011/3/11， 名取市撮影，海上保安庁提供）

ではない. 浸水高をエリア北側・南側で比べると, 汀線 から $1 \mathrm{~km}$ の範囲では北側の方が大きくなっており，両者 に明確な差が現れている，また，大砂丘背後では，汀線 から 300mにも関わらず，浸水高が 5.7〜6.9 [T.P.m]となっ ており，エリア北側の汀線から $1.1 \mathrm{~km}$ に位置する浸水高 と同程度の大きさまで減少させている，また，津波来襲 時における航空斜め写真 (図-6) を見ると, 大砂丘は水 没せず，その背後の津波浸水高を大幅に低減させている 様子が伺える. このように，今回の大砂丘は浻岸方向幅 は狭いものの, 大砂丘背後近傍では浸水高を明瞭に低減 させている.

一方，旭市の結果に関して，被害の大きかった飯岡地 区では, 浸水高は最大 6[T.P.m]程度であり, 陸側に行くと やや低下し 5[T.P.m]程度となる.この最大浸水高は, 同工 リアの砂丘天端高さ（図-2（b））と概ね一致している. また，この時の浸水深は最大 $3 \mathrm{~m}$ であるが，陸側へ $100 \mathrm{~m}$ 離れた地点では，その浸水深が $2 \mathrm{~m}$ 低下している. これ は, 標高の変化と対応しており, 名取市と比べて地形勾 配が急であり，それが被害エリアが海岸付近に集中した 要因である. 次に, 砂丘背後に着目すると, 汀線から最 も近い地点にも関わらず, 浸水高 5[T.P.m], 浸水深 $2 \mathrm{~m}$ と 低い. 汀線からの距離が同じ所の浸水深を比べても, 全 体的に, 砂丘背後の方が飯岡地区と比べて小さく, 砂丘 による津波浸水高・浸水深の低下が顕著であることが分 かる.さらに, 目那川河口部では, 浸水高や浸水深は飯 岡地区と概ね同程度となっている. この河口部は幅 $20 \mathrm{~m}$ と広くないが，この狭いエリアを津波が遡上し，陸上部 に大きな被害を与えている.

今回の浸水高や砂丘断面形より, 名取市と旭市ではど ちらも砂丘天端と同程度の高さの津波が来襲している. 両者の砂丘背後の浸水高を比べると, 沿岸幅が狭い名取 市の大砂丘の場合には，浸水高低減効果が限定的であつ たが，沿岸方向に十分長い旭市では，背後地全体にわた り浸水高を低下させている. これより, 浸水高と砂丘の 標高が同程度であり, かつ, 砂丘の沿岸方向長さが十分 あれば，津波被害を軽減させることが十分可能であるこ とが示された。

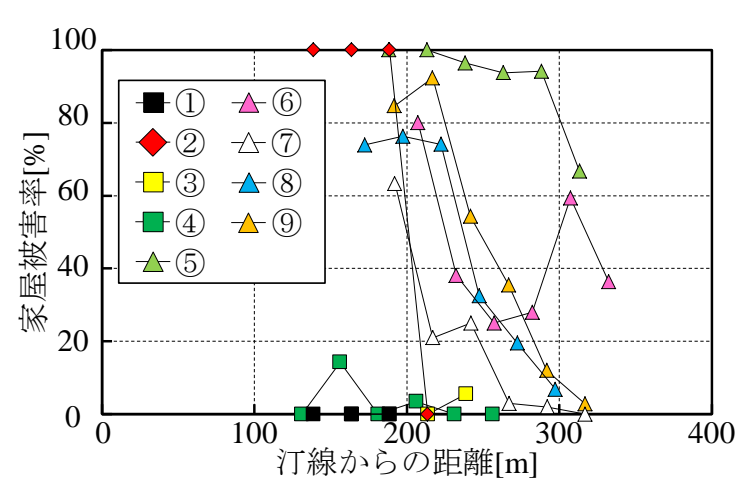

図-7 旭市の各区間における家屋被害率分布

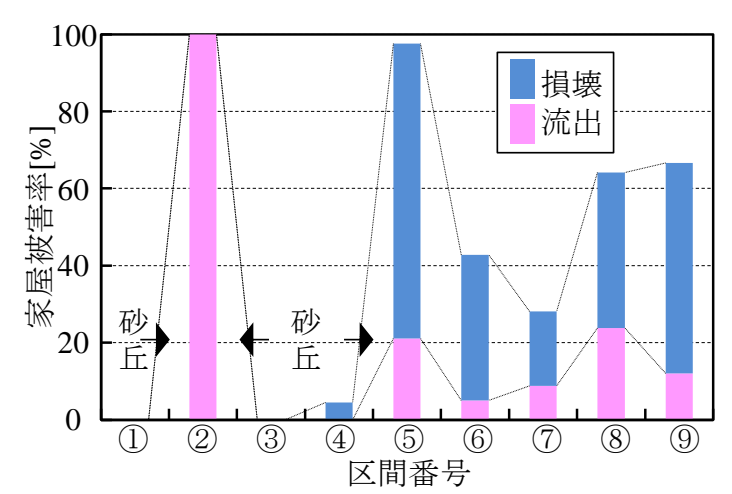

図-8＼cjkstart沿岸方向における家屋被害率の変化

\section{b) 家屋被害率}

同様の比較を家屋被害率でも行う. 図-7 は, 旭市の調 査対象範囲を 9 つに分類し（図-4），その各区間におけ る家屋被害率の空間分布を示している。ここでは， $25 \mathrm{~m}$ 間隔で家屋被害率 (=流出十損壊) を算出している.これ より，砂丘が存在する区間(1)，(3)，(4)では，家屋被害が ほとんど生じていないが，砂丘の切れ間であり河口部の 区間(2)砂丘が無い区間(5)〜9では被害率が顕著に高い. 特に，区間(5)では，防潮林があるにも関わらず，被害が 大きい. これらの様子をよりクリアに確認するため, 各 区間における平均家屋被害率をまとめたものを図-8に示 す.ここでは，家屋被害が概ね $100 \mathrm{~m}$ 内に収まっている ことを考慮して, 家屋が存在する最も海側の地点から陸 側に $100 \mathrm{~m}$ の範囲内において，家屋被害率（流出，損壊） を平均している. これより, 砂丘背後区間(1), (3), (4)で は流出被害を受けた家屋は無いが，砂丘の切れ目である 目那川河口の区間(2)では流出率が 100\%であった。砂丘 背後区間と隣接する区間(5)では，流出・損壊家屋の被害 率は 90\%を超えており，家屋被害率に対して砂丘の有無 が大きく影響していることが分かる．以上の結果から， 津波の浸水高約 6[T.P.m] と砂丘の標高約 6[T.P.m]が同様の 場合において，砂丘は津波の威力を減衰させ，家屋への 被害を低減させることが可能であることが明らかとなっ た。 


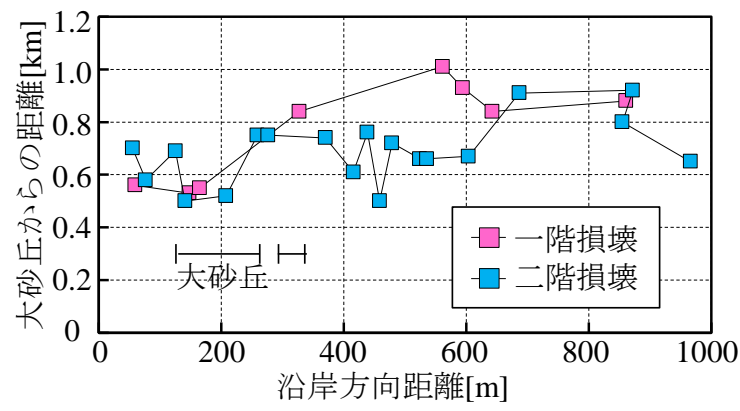

図-9木造家屋被害の変化

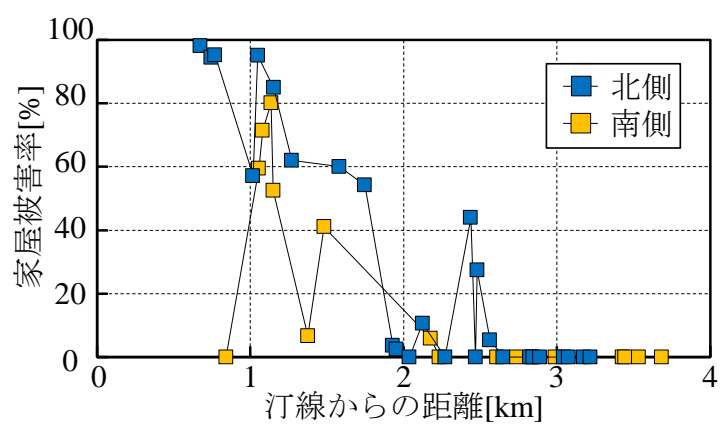

図-10 名取市における家屋被害率分布

次に, 名取市の大砂丘背後の家屋被害状況を抽出する ために，大砂丘やその周囲の背後地にて，最も汀線に近 い「一階損壊」, 「二階損壊」の木造家屋を抽出し，そ れの沿岸方向分布を図-9 に示す. 大砂丘背後では広浦沿 いの「一階損壊」家屋 $(=0.53 \mathrm{~km})$ が存在するが，大砂丘 以外のところでは $0.84 \mathrm{~km}$ 以上からしか存在せず，「二階 損壞」家屋も同様な傾向である.このように, 沿岸方向 長さが $200 \mathrm{~m}$ と短い大砂丘においても背後地の家屋被害 を減少させていることが分かる．また，名取市サイトの 北側と南側における流出家屋被害率の分布を比べると(図 $-10)$, 汀線から $2 \mathrm{~km}$ 程度まで南側の被害率が北側よりも 小さく, 図-5（a）の浸水高と対応している. 前述したよ うに，このエリア南側に存在する小砂丘と防潮林による 減災効果が現れている.

\section{4. 結論}

本研究では，津波被害が大きかった宮城県名取市沿岸 部と千葉県旭市を対象として, 計 8731 棟の家屋に関する 津波被害状況を調査し，海岸砂丘の津波防災・減災効果 に関して検討した。 その結果, 砂丘背後では両市とも明 らかな浸水深の低下が確認され，浸水高と砂丘の高さが 同じならば,家屋被害も減少することが明らかになった. しかしながら，砂丘が断続している場合は効果が薄れる ことも示された. 以上のことから, より効果的に海岸線 における津波対策を行うためには，連続し，想定された 津波高と同程度の砂丘を造成することが望ましい.
謝辞 : 本研究は，三井物産環境基金・2011 年度復興助成 （研究代表者：二瓶泰雄）によって実施された。浸水深 計測で用いた Static GPS の使用に際しては, 東京理科大学 理工学部土木工学科佐伯昌之准教授に多大なご協力を頂 いた.ここに記して深甚なる謝意を表す.

\section{参考文献}

1) Mori, N., T. Takahashi and The 2011 Tohoku Earthquake Tsunami Joint Survey Group: Nationwide post event survey and analysis of the 2011 Tohoku earthquake tsunami, Coastal engineering Joumal, Vol.54, No.1, 1250001(27pages), 2012

2) Ogasawara, T., Y. Matsubayashi, S. Sakai and T. Yasuda: Characteristics of the 2011Tohoku earthquake and tsunami and its impact on the northem Iwate coast, Coastal Engineering Joumal, Vol.54, No.1, 1250003(16pages), 2012

3) Gokon, H. and S. Koshimura: Mapping of building damage of the 2011 Tohoku Earthquake Tsunami in Miyagi Prefecture, Coastal Engineering Joumal, Vol.54, No.1, 1250006(12pages) ,2012

4) 国土交通賞東北地方整備局仙台河川国道事務所 : 東日本代 震災からの復旧仙台南部海岸の取り組み http://www.thr.mlit.go.jp/bumon/b00037/k00290/river-hp/kasen/shinsaika nren/data/9 kasenn\%20kaigannkannkei2senndaiwannanbukaigannotori kumi.pdf, 2012. (閲覧 : 2012年9月 14 日)

5)国土交通省水管理 - 国土保全局海岸室： http://www.bousai.go.jp/jishin/chubou/taisaku_nankaitrough/2/1.pdf ， 2012. (閲覧 : 2012年9月 14 日)

6) 小笠原敏記・松林由里子・堺茂樹・安田孝志 : 岩手県北部 の沿岸における津波被害の特徵, 東北地方太平洋沖地震津 波に関する合同調査報告会予稿集，pp.10-15，2011.

7) 首藤伸夫 : 防潮林の津波に対する効果と限界, 海岸工学講 演会論文集, Vol.32, pp.465-469, 1985.

8) 原田賢治，今村文彦：防潮林による津波減衰効果の評価と 減災のための利用の可能性, 海岸工学論文集, Vol.50, pp.341-345, 2003.

9) Danielsen, F., M. K. Sørensen, M. F. Olwig, V. Selvam, F. Parish, N. D. Burgess, T. Hiraishi, V.M. Karunagaran, M. S. Rasmussen, L. B. Hansen, A. Quarto and N. Suryadiputra: The Asian tsunami: a protective role for coastal vegetation, Science, Vol. 310, 643p., 2005.

10) Tanaka, N., Y. Sasaki, M. I. M. Mowjood, K. B. S. N. Jinadasa and S. Homchuen: Coastal vegetation structures and their functions in tsunami protection: experience of the recent Indian Ocean tsunami, Landscape and Ecological Engineering, Vol.3, No.1,pp.33-45, 2007.

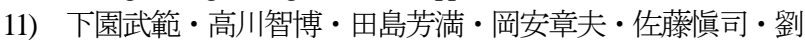
海江 : 2011年東北地方太平洋沖地震津波による茨城県・千 葉県沿岸域における被害, 土木学会論文集 B2 (海岸工学), Vol.67, No.2, pp.I_296-I_300, 2011.

12）二瓶泰雄，前川俊明，大嶋李香，柳沢舞美 : 宮城県名取市 沿岸部における津波被害関数の推定と海岸砂丘の減災効果, 土木学会論文集 B2 (海岸工学), Vol.68, No.2, pp.I_276-I_280, 2012.

13) 国土地理院 - 2 万 5 千分 1 浸水範囲概況図: http://www.gsi.go.jp/kikaku/kikaku40014.html.（閲覧 : 2011 年 5 月 2 日)

14）庄司学，森山哲雄，幸左賢二，松富英夫，鴫原良典，村嶋 陽一 : 2006年ジャワ島南西沖地震津波による家屋等構造物 の被災分析, 海岸工学論文集, Vol.54, No.2, pp.861-865, 2007.

(2012. 9.30 受付) 